\title{
To Evaluate and Compare Effect of Calcium Hydroxide with Different Vehicles on the Mineral Content of Root Dentin: An EDAX Analysis
}

\author{
${ }^{1}$ Shweta Bagmar, ${ }^{2}$ Sameer Jadhav, ${ }^{3}$ Vivek Hegde, ${ }^{4}$ Vignesh Dixit, ${ }^{5}$ Vijay Kumar L Shiraguppi
}

\section{ABSTRACT}

Introduction: The aim of this study is to evaluate and compare effect of calcium hydroxide with different vehicles on the mineral content of root dentin-an EDAX analysis, after 1, 2 and 3 weeks.

Materials and methods: Seventy-five freshly extracted single rooted teeth were selected for study and randomly divided into 5 groups. An access to the root canal of all teeth was prepared using a round and cylindrical bur (Mani Inc.). Canals were instrumented with stainless steel K file (Dentsply Maillefer, Johnson City, TN) so that the file extended beyond the apical foramen by $1 \mathrm{~mm}$. And then canals were prepared to a size F2 with hand proTaper (Dentsply Maillefer, Johnson City, TN). Copious irrigation with sterile saline was done. Sample of group 1-were sealed apically with bonded composite resin and coronally with cotton pellet and bonded composite resin. Samples of group 2-were filled with thick slurry made with calcium hydroxide and saline using lentulo spiral (Henry Schein). To ensure intimate contact with the canal walls, excess calcium hydroxide was intentionally extruded past the apex. Root canals were sealed apically and coronally in the same manner as in previous group. Samples of group 3-Calcigel (water based calcium hydroxide, Prevest Denpro Ltd), group 4-Metapex (oil based calcium hydroxide, Meta BioMed) and group 5-Calcium hydroxide and propylene glycol, were prepared in the same manner as previous group. The samples were maintained at room temperature and $100 \%$ humidity in incubator. After 7 days, 5 samples from each group were removed from incubator and the roots were vertically sectioned into $1 \mathrm{~mm}$ thick specimen with water cooled diamond disk. Each section of sample was then evaluated under EDAX. After 14th and 21 st day 5 samples of each group were removed and tested in same manner as mentioned previously.

Keywords: Calcigel, Metapex, Propylene glycol, EDAX analysis.

How to cite this article: Bagmar S, Jadhav S, Hegde V, Dixit V, Shiraguppi VKL. To Evaluate and Compare Effect of Calcium Hydroxide with Different Vehicles on the Mineral Content of Root Dentin: An EDAXAnalysis. World J Dent 2014;5(3):170-173.

Source of support: Nil

Conflict of interest: None

\footnotetext{
${ }^{1}$ Student, ${ }^{2,4}$ Professor, ${ }^{3}$ Head, ${ }^{5}$ Reader

${ }^{1-5}$ Department of Conservative Dentistry and Endodontics MA Rangoonwala Dental College and Research Center, Pune Maharashtra, India
}

Corresponding Author: Shweta Bagmar, Student, Department of Conservative Dentistry and Endodontics, MA Rangoonwala Dental College and Research Center, Pune, Maharashtra, India Phone: 02026430960, e-mail: shweta.bagmar02@gmail.com

\section{INTRODUCTION}

Calcium hydroxide was introduced in endodontics by Hermann in $1920 .{ }^{1}$ Use of calcium hydroxide in dentistry is well established and wide spread. It has been used extensively in multiple endodontic applications. $\mathrm{Ca}(\mathrm{OH})_{2}$ is widely accepted as an interappointment intracanal medicament. ${ }^{2}$ Calcium hydroxide application have been well documented in the scientific literature, ${ }^{3-6}$ including its use for root canal disinfection, the induction of calcification response, and the promotion of apexification. When placed within the root canal system, $\mathrm{Ca}(\mathrm{OH})_{2}$ disassociates into calcium and hydroxyl ions, ${ }^{7}$ and the hydroxyl ions diffuse through the dentinal tubules. ${ }^{8,9}$ The high $\mathrm{pH}$ and antimicrobial properties of $\mathrm{Ca}(\mathrm{OH})_{2},{ }^{10}$ combined with the permeability of dentin, ${ }^{11,12}$ may account for its effectiveness as an intracanal inter-appointment medicament. However, when $\mathrm{Ca}(\mathrm{OH})_{2}$ is used in these applications, therapy may extend from months to years before the desired effects are achieved. ${ }^{13,14}$ Furthermore, it has been observed that $\mathrm{Ca}(\mathrm{OH})_{2}$ treated immature teeth show a high failure rate because of an unusual preponderance of root fracture and it has been suggested that changes in the physical properties of dentin by the $\mathrm{Ca}(\mathrm{OH})_{2}$ medicament may be responsible. ${ }^{15,16}$

Exposure of root dentin to the bioactive effects of $\mathrm{Ca}(\mathrm{OH})_{2}$ may affect its physical characteristics and could have important clinical implications for the treatment of traumatized teeth and immature teeth with nonvital pulps. The purpose of the present study was to determine if intracanal exposure to $\mathrm{Ca}(\mathrm{OH})_{2}$ for 30 and 180 days alters the fracture resistance of human root dentin.

\section{MATERIALS AND METHODS}

Seventy-five freshly extracted single rooted single canal human teeth were chosen for study. Before preparation teeth were stored in sodium hypochloride for 24 hours to dissolve any tissue on the root surface. The teeth were than scaled with an ultrasonic scaler (EMS, Mectron) to remove any deposits, concretions, calculus if present on root surface.

An access to the root canal of all teeth was prepared using a round and cylindrical bur (Mani Inc.). Canals were instrumented to a size 8 with stainless steel K file (Dentsply Maillefer, Johnson City, TN) so that the file extended beyond 
the apical foramen by $1 \mathrm{~mm}$. The canals were instrumented with stainless steel 10 number K-file (Dentsply Maillefer, Johnson City, TN). And then prepared to size F2 with hand proTaper (Dentsply Maillefer, Johnson City, TN). All files were extended $1 \mathrm{~mm}$ beyond the apical foramen and copious irrigation with sterile saline was completed between file systems. Canals were then thoroughly rinsed with saline solution. All teeth having identical preparation were assigned to one of the five groups, so that each group was comprised of 15 samples.

Root canals of teeth in group I were sealed apically with bonded composite resin (Tetric Ceram) and coronally with a cotton pellet and bonded composite resin. Root canal of teeth in group II were filled with $\mathrm{Ca}(\mathrm{OH})_{2}$ mixed to thick slurry with sterile saline. To insure intimate contact with the canal walls and a dense fill of canal space and excess $\mathrm{Ca}(\mathrm{OH})_{2}$ was intentionally extruded past the apex using lentulospiral (Dentsply). The root canals in group III were filled with Calcigel, group IV were filled with metapex, group $\mathrm{V}$ were filled with calcium hydroxide and propylene glycol. As with group I the teeth in groups II, III, IV and V were sealed apically with bonded composite and coronally with a cotton pellet and bonded composite. Samples were stored in saline $0.9 \%$ saline solution at room temperature in plastic container. After 7, 14, 21 days 5 samples from each group were removed from saline storage container and roots were vertically sectioned into two parts with water cooled diamond saw. Samples were then subjected to EDAX analysis.

\section{EDAX Analysis}

Energy dispersive X-ray spectroscopy is an analytical technique used for the elemental analysis or chemical characterization of a sample. It is one of the variants of X-ray fluorescence spectroscopy which relies on the investigation of a sample through interactions between electromagnetic radiation and matter, analyzing $\mathrm{X}$-rays emitted by the matter in response to being hit with charged particles.
Its characterization capabilities are due in large part to the fundamental principle that each element has a unique atomic structure allowing X-rays that are characteristic of an element's atomic structure to be identified uniquely from one another. EDAX analysis was carried out for calculating percentage of mineral before and after preparation and $\mathrm{Ca}(\mathrm{OH})_{2}$ treatment.

\section{RESULTS}

\section{At Day 7}

From the Tables 1 and 2 and Graphs $1 \mathrm{~A}$ and B it can be seen that:

- The average calcium is significantly higher in saline group compared to control, Calcigel, metapex and propylene groups ( $\mathrm{p}<0.01$ for all).

- The average calcium is significantly higher in control group compared to Calcigel and propylene groups $(\mathrm{p}<0.01$ for all).

- The average calcium is significantly higher in metapex group compared to Calcigel and propylene groups $(\mathrm{p}<$ 0.01 for all).

- The average phosphorus is significantly higher in control, saline and metapex groups compared to Calcigel and propylene groups $(\mathrm{p}<0.01$ for all).

\section{At Day 14}

- The average calcium is significantly higher in Saline group compared to control, Calcigel, metapex and propylene groups ( $\mathrm{p}<0.01$ for all).

- The average calcium is significantly higher in control group compared to Calcigel and propylene groups $(\mathrm{p}<$ 0.01 for all).

- The average calcium is significantly higher in metapex group compared to Calcigel and propylene groups $(\mathrm{p}<$ 0.01 for all).

- The average phosphorus is significantly higher in control, saline and metapex groups compared to Calcigel and propylene groups ( $\mathrm{p}<0.01$ for all).

Table 1: The distribution of calcium and phosphorus levels across five study groups at each stage (The intergroup distributions)

\begin{tabular}{llllll}
\hline & Control & Saline & Calcigel & Metapex & Propylene glycol \\
\hline Day 7 & & & & \\
Calcium (\%) & $28.9 \pm 0.93$ & $30.8 \pm 0.33$ & $26.2 \pm 0.22$ & $28.6 \pm 0.30$ & $25.5 \pm 0.25$ \\
Phosphorus (\%) & $13.2 \pm 0.20$ & $13.2 \pm 0.27$ & $12.1 \pm 0.17$ & $13.2 \pm 0.26$ & $11.9 \pm 0.29$ \\
Day 14 & & & & \\
Calcium (\%) & $28.8 \pm 0.83$ & $30.5 \pm 0.97$ & $25.9 \pm 0.84$ & $28.3 \pm 0.53$ & $25.3 \pm 0.67$ \\
Phosphorus (\%) & $13.1 \pm 0.44$ & $12.9 \pm 0.54$ & $11.9 \pm 0.47$ & $12.9 \pm 0.30$ & $11.8 \pm 0.44$ \\
Day 21 & & & & \\
Calcium (\%) & $28.7 \pm 0.79$ & $30.2 \pm 0.63$ & $25.6 \pm 0.94$ & $27.9 \pm 0.66$ & $25.1 \pm 0.66$ \\
Phosphorus (\%) & $13.0 \pm 0.44$ & $12.7 \pm 0.44$ & $11.5 \pm 0.44$ & $12.7 \pm 0.34$ & $11.6 \pm 0.38$ \\
\hline Values are mean & & & &
\end{tabular}

Values are mean \pm standard deviation 
Table 2: The statistical comparison of calcium and phosphorus levels across five study groups at each stage (The intergroup comparisons)

\begin{tabular}{|c|c|c|c|c|c|c|c|c|c|}
\hline $\begin{array}{l}\text { Control vs } \\
\text { saline }\end{array}$ & $\begin{array}{l}\text { Control } \\
\text { vs } \\
\text { calcigel }\end{array}$ & $\begin{array}{l}\text { Control vs } \\
\text { metapex }\end{array}$ & $\begin{array}{l}\text { Control vs } \\
\text { propylene } \\
\text { glycol }\end{array}$ & $\begin{array}{l}\text { Saline vs } \\
\text { calcigel }\end{array}$ & $\begin{array}{l}\text { Saline vs } \\
\text { metapex }\end{array}$ & $\begin{array}{l}\text { Saline vs } \\
\text { propylene } \\
\text { glycol }\end{array}$ & $\begin{array}{l}\text { Calcigel } \\
\text { vs } \\
\text { metapex }\end{array}$ & $\begin{array}{l}\text { Calcigel vs } \\
\text { propylene } \\
\text { glycol }\end{array}$ & $\begin{array}{l}\text { Metapex } \\
\text { vs } \\
\text { propylene } \\
\text { glycol }\end{array}$ \\
\hline
\end{tabular}

\begin{tabular}{|c|c|c|c|c|c|c|c|c|c|c|}
\hline \multicolumn{11}{|l|}{ Day 7} \\
\hline Calcium & $0.001(\mathrm{~S})$ & $0.001(\mathrm{~S})$ & 0.663 (NS) & $0.001(\mathrm{~S})$ & $0.001(\mathrm{~S})$ & $0.001(\mathrm{~S})$ & $0.001(\mathrm{~S})$ & 0.001 (S) & $0.044(\mathrm{~S})$ & $0.001(\mathrm{~S})$ \\
\hline Phosphorus & 0.962 (NS) & $0.001(\mathrm{~S})$ & 0.986 (NS) & $0.001(\mathrm{~S})$ & $0.001(\mathrm{~S})$ & 0.999 (NS) & $0.001(\mathrm{~S})$ & $0.001(\mathrm{~S})$ & 0.779 (NS) & $0.001(\mathrm{~S})$ \\
\hline $\begin{array}{l}\text { Day } 14 \\
\text { Calcium }\end{array}$ & $0.001(\mathrm{~S})$ & $0.001(\mathrm{~S})$ & 0.718 (NS) & $0.001(\mathrm{~S})$ & $0.001(\mathrm{~S})$ & $0.001(\mathrm{~S})$ & $0.001(\mathrm{~S})$ & $0.001(\mathrm{~S})$ & 0.479 (NS) & $0.001(\mathrm{~S})$ \\
\hline Phosphorus & 0.888 (NS) & $0.001(\mathrm{~S})$ & 0.987 (NS) & $0.001(\mathrm{~S})$ & $0.001(\mathrm{~S})$ & 0.993 (NS) & $0.001(\mathrm{~S})$ & $0.001(\mathrm{~S})$ & 0.993 (NS) & $0.001(\mathrm{~S})$ \\
\hline $\begin{array}{l}\text { Day } 21 \\
\text { Calcium }\end{array}$ & $0.004(\mathrm{~S})$ & $0.001(\mathrm{~S})$ & 0.237 (NS) & $0.001(\mathrm{~S})$ & $0.001(\mathrm{~S})$ & & $0.001(\mathrm{~S})$ & $0.001(\mathrm{~S})$ & 0.654 (NS) & $0.001(\mathrm{~S})$ \\
\hline Phosphorus & 0.420 (NS) & $0.001(\mathrm{~S})$ & 0.644 (NS) & $0.001(\mathrm{~S})$ & $0.001(\mathrm{~S})$ & 0.996 (NS) & $0.001(\mathrm{~S})$ & $0.001(\mathrm{~S})$ & 0.994 (NS) & $0.001(\mathrm{~S})$ \\
\hline
\end{tabular}

Values are p-values, obtained by one-way analysis of variance (ANOVA) with Tukey's correction for multiple comparisons. p-value < 0.05 are considered to be statistically significant. S: Statistically significant, NS: Statistically nonsignificant
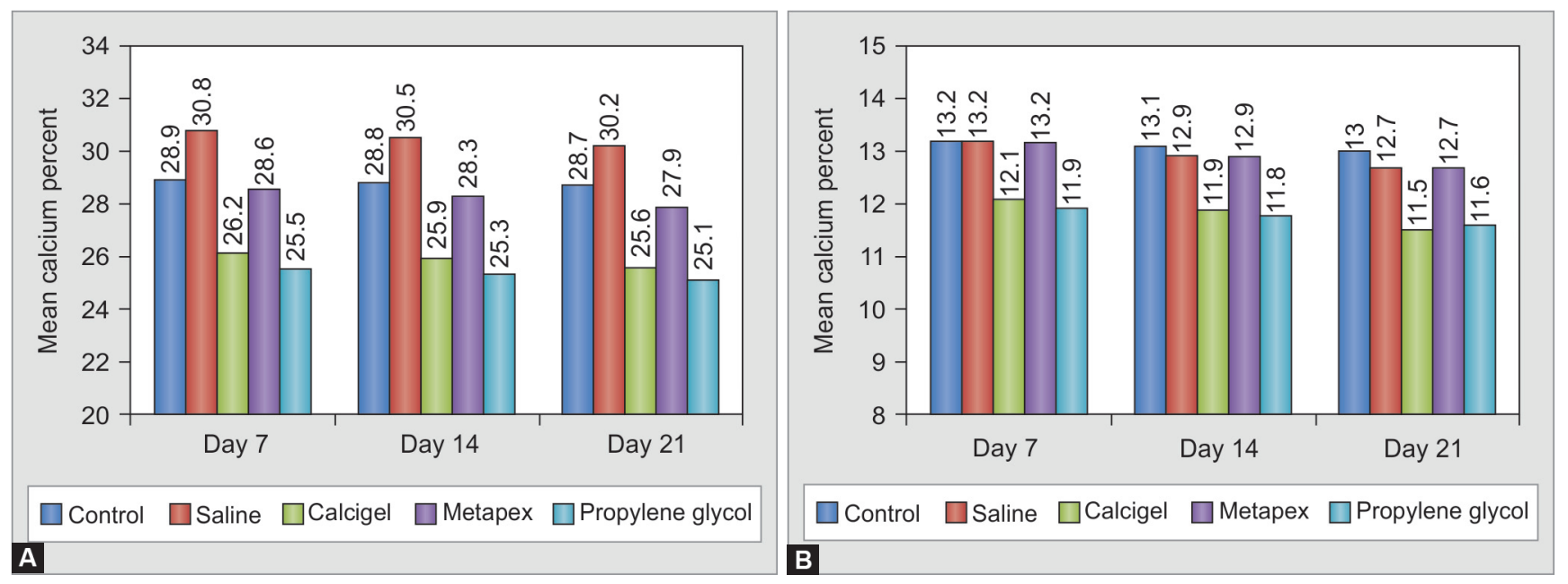

Graphs 1A and B: (A) The distribution of calcium levels across five study groups at each, (B) the distribution of phosphorus levels across five study groups at each stage (the intergroup distributions)

\section{At Day 21}

The average calcium is significantly higher in saline group compared to control, Calcigel, metapex and propylene groups ( $\mathrm{p}<0.01$ for all).

The average calcium is significantly higher in control group compared to Calcigel and propylene groups $(\mathrm{p}<0.01$ for all).

The average calcium is significantly higher in metapex group compared to Calcigel and propylene groups ( $p<0.01$ for all).

The average phosphorus is significantly higher in control, saline and metapex groups compared to Calcigel and propylene groups ( $\mathrm{p}<0.01$ for all).

\section{DISCUSSION}

The purpose of this research was to examine the possible deleterious effects of $\mathrm{Ca}(\mathrm{OH})_{2}$ on human root dentin. $\mathrm{Ca}(\mathrm{OH})_{2}$ is a material used in endodontic treatment, often over extended periods of time. Extracted teeth were selected because the effects of long term $\mathrm{Ca}(\mathrm{OH})_{2}$ on human dentin has not been previously studied. The forces placed on human teeth in vivo are different than those placed on the dentin disks used in this study. However, it was felt that the current protocol would account for the variability of human dentin, not only between different teeth but also along the length of an individual root.

Addition of vehicles seems to prevent dentin phosphorus release. The vehicles may form a protective film on hydroxyapatite crystals or combine with $\mathrm{Ca}(\mathrm{OH})_{2}$, thus reducing the attractive action on inorganic dentin components.

Propylene glycol is a clear and odorless liquid with a characteristic taste that resembles that of glycerin. Its wide application in endodontics as a vehicle for intracanal medicaments is attributable to its strong antibacterial action against microorganisms commonly found in infected root canals. Another advantage of this substance is its consistency, which improves the handling qualities of the paste. Simon et $\mathrm{al}^{17}$ recommend propylene glycol as the best vehicle in $\mathrm{Ca}(\mathrm{OH})_{2}$ preparation. 
Metapex contains silicone oil as its vehicle. The superior properties of metapex may be due to the combination with iodoform and to the viscous and oily vehicle, which may prolong the action of the medicament. ${ }^{18}$

In a retrospective study, $\mathrm{Cvek}^{15}$ investigated 885 luxated nonvital incisors treated with $\mathrm{Ca}(\mathrm{OH})_{2}$ over a period ranging from 3 to 54 months with the mean value for immature teeth being 24 and 11 months for mature teeth. Of the 885 teeth, 168 suffered a cervical root fracture within the follow-up period, which ranged from 3.5 to 5 years.

The findings of this study may appear to support the contention that long term exposure to $\mathrm{Ca}(\mathrm{OH})_{2}$ alters the physical properties of dentin. This may be a result of a change in the organic matrix. ${ }^{19}$ Average calcium significantly dropped at day 21 compared to day 7 in saline and metapex group ( $\mathrm{p}<0.005$ for both) and the average phosphorus significantly dropped at day 21 compared to day 7 in saline, Calcigel, metapex, propylene glycol group ( $\mathrm{p}<0.05$ for all).

It has been shown that $\mathrm{Ca}(\mathrm{OH})_{2}$ dissolves pulp tissue, ${ }^{20,21}$ a process that may occur by denaturation and hydrolysis. In addition, the $\mathrm{pH}$ increase observed after exposure to $\mathrm{Ca}(\mathrm{OH})_{2}$ may also reduce the organic support of the dentin matrix..$^{11,12}$ These processes may disrupt the interaction of the collagen fibrils and hydroxyapatite crystals that could negatively influence the mechanical properties of dentin.

\section{CONCLUSION}

Within the limitation of this in vitro study, oil based calcium hydroxide, saline based calcium hydroxide showed significant difference in calcium and phosphorus content as compared to Calcigel and propylene glycol on root dentin. Water based $\mathrm{Ca}(\mathrm{OH})_{2}$ was less derogative on root dentin surface. Further studies, e.g. ex vivo/in vivo would be helpful to reaffirm the above results.

\section{REFERENCES}

1. Hermann BW. Calcium hydroxydals Mittel Zum Behandeln und Fullen Von Zahnwurzelkana len. Wuzburg: Med Diss, 1920.

2. Bystrom A, Claesson R, Sundqvist G. The antibacterial effect of camphorated paramonochlorophenol, camphorated phenol and calcium hydroxide in the treatment of infected root canals. Endod Dent Traumatol 1985;1(5):170-175.

3. Estrela C, Pe' cora JD, Souza-Neto MD, Estrela CR, Bammann LL, Pimenta FC. Effect of vehicle on antimicrobial properties of calcium hydroxide pastes. Braz Dent J 1999;10(2):63-72.
4. Fava LR, Saunders WP. Calcium hydroxide pastes: classification and clinical indications. Int Endod J 1999;32(4):257-282.

5. Siqueira JF Jr, Lopes HP. Mechanisms of antimicrobial activity of calcium hydroxide: critical review. Int Endod J 1999;32(5): 361-369.

6. Hammarström LE, Blomlöf LB, Feiglin B, Lindskog SF. Effect of calcium hydroxide treatment on periodontal repair and root resorption. Endod Dent Traumatol 1986;2(5):184-189.

7. Pashley DH. Dentin: a dynamic substrate — a review. Scanning Microsc 1989;3(1):161-174.

8. Pashley DH, Livingston MJ, Outhwaite WC. Rate of permeation of isotopes through human dentin, in vitro. J Dent Res 1977;56(1): 83-88.

9. Foreman PC, Barnes IE. Review of calcium hydroxide. Int Endod J 1990;23(6):283-297.

10. Tamburic SD, Vuleta GM, Ognjanovic JM. In vitro release of calcium and hydroxylions from two types of calcium hydroxide preparation. Int Endod J 1993;26(2):125-130.

11. Tronstad L, Andreasen JO, Hasselgren G, Kristerson L, Riiss I. $\mathrm{pH}$ changes in dental tissues after root canal filling with calcium hydroxide. J Endod 1980;7(1):17-21.

12. Nerwich A, Figdor D, Messer HH. pH changes in root dentin over a 4-week period following root canal dressing with calcium hydroxide. J Endod 1993;19(6):302-306.

13. Sheehy EC, Roberts GJ. Use of calcium hydroxide for apical barrier formation and healing in nonvital immature permanent teeth: a review. Br Dent J 1997;183(7):241-246.

14. Dannenberg JL. Pedodontic endodontics. Dent Clin North Am 1974;18(2):367-377

15. Cvek M. Prognosis of luxated nonvital maxillary incisors treated with calcium hydroxide and filled with gutta-percha. A retrospective clinical study. Endod Dent Traumatol 1992;8(2): 45-55.

16. Stormer K, Jacobsen I, Attramadal A. Hvor funkjonsdyktige blir rottfylte unge permanente incisiver? In: Nordisk forening for pedodonti. Bergen, Norway: Aarsmote, 1988.

17. Simon ST, Bhat KS, Francis R. Effect of four vehicles on the $\mathrm{pH}$ of calcium hydroxide and the release of calcium ion. Oral Surg Oral Med Oral Pathol Oral Radiol Endod 1995;80(4):459-464.

18. Gautam S, Rajkumar B, Landge SP, Dubey S, Nehete P, Boruah LC. Antimicrobial efficacy of Metapex (Calcium hydroxide with Iodoform formulation) at different concentrations against selected microorganisms - An in vitro study. Nepal Med Coll J 2011;13(4):297-300.

19. Andreasen JO, Farik B, Munksgaard EC. Long-term calcium hydroxide as a root canal dressing may increase risk of root fracture. Dent Traumatol 2002;18(3):134-137.

20. Anderson M, Lund A, Andreasen JO, Andreasen FM. In vitro solubility of human pulp tissue in calcium hydroxide and sodium hypochlorite. Endod Dent Traumatol 1992;8(3):104-108.

21. Hasselgren G, Olsson B, Cvek M. Effects of calcium hydroxide and sodium hypochlorite on the dissolution of necrotic porcine muscle tissue. J Endod 1988;7(3):17-21. 